\title{
TERCENTENARY OF COMENIUS
}

$\mathrm{O}_{1}$ N October 24, the tercentenary of the visit to England in 1641 of Jan Amos Komensky (Comenius), the famous writer on education, was observed in the Senate House of the University of Cambridge.

The official representatives were as follows: Government of Czechoslovakia, Dr. E. Benes, president; Government of the U.S.S.R., M. Maisky, ambassador ; Government of the Netherlands, M. Bolkestein, minister of education ; Government of Poland, Count Racyński, foreign minister and ambassador; Government of Yugoslavia, M. Milanović, under-secretary of state for foreign affairs; Government of Sweden; the Board of Education, Dr. R. Fitzgibbon Young; the Royal Society, Sir Henry Dale, Sir William Bragg, Sir Frederick Gowland Hopkins, Sir Charles Sherrington; the Moravian Church, The Right Rev. C. H. Shaine; the British Council, Prof. B. Ifor Evans.

In his opening discourse Dr. Benes, President of Czechoslovakia, described Comenius's plans for peace leagues and his place in history as a great European. This pastor, later bishop of the Moravian Brethren, a brilliant pioneer in educational methods, stood in his breadth of views as a veritable giant above his contemporaries. President Benes pointed out that the position of the Czech people, surrounded as they have been for a thousand years by other peoples, in the heart of Europe, has disposed them to a natural panEuropeanism. The necessity of being on good terms with Germans to the north, Latins to the west, Slavs to the east, and the Balkans to the south, early implanted in their minds ideals of internationalism. President Benes emphasized the happy nature of the stimulus between English and Czech culture which occurred when in 1641 Comenius was invited by Parliament to visit Great Britain and prepare plans for the remodelling of education and the establishment of a "Pansophic College".

Comenius's place as an educator was next dealt with in a brilliant and moving speech by Mr. J. L. Paton, formerly high master of Manchester Grammar School and later president of University College, Newfoundland. Comenius represented all the ideas which have successfully triumphed in modern education; he was against class distinctions in the school, he was in favour of the education of women, he wanted to introduce science, music and handwork at the expense of the Latin grammar which at that time was universally learnt by heart, he desired schools to be happy workshops of humanity (in his own words) rather than the torture-chambers of youth that they were. In the "Didactica Magna", he summarized his basic belief, that man is a rational creature situated by God among visible creatures, the natures and properties of which he must of necessity know. Hence Comenius's interest in science"the new or experimental philosophy"-arose out of his interest in education, and that in turn sprang from his theoretical position as one of the great Christian humanists.

Comenius never felt that science would clash with revelation: "Christ", he said, "called himself not Tradition, but Truth itself." Though he himself was, like most of his contemporaries, a great believer in the literal truth of the Scriptures, he nevertheless, like Sir Thomas Browne, insisted that Christians ought to pay at least equal attention to that other bible, Nature, "that open and publick manuscript which lies expans'd unto the eyes of all'.

Prof. J. D. Bernal, continuing Mr. Paton's theme in the direction of the sciences, pointed out that though Comenius made no scientific discoveries himself, he brought it about by his new ideas on education that men should arise who could make scientific discoveries. Comenius was a man very comparable with Boyle, who also combined a passionate belief in the growth of natural science with a universalism which desired the propagation of the Gospel in those far parts of the world with which the voyages of exploration had made Europeans familiar.

Like Boyle, Comenius was associated with New England, and was even invited to Harvard College. This Christian universalism was the mainspring of the interest of such men as Comenius and Wilkins in a universal language as well as in universally applicable methods of education, which should deal with things and actions, not words and ideas. From the Unitas Fratrum (the Moravian Brethren) came the ideas of unitas and communitas which dissolved the secrecy of the alchemists and astrologers into the liquid homogeneity of a higher level of international collaboration in science, in religion and in education. We rightly commemorate Comenius, the spiritual father of the "Invisible College", and the patron saint of those who are conscious of the social relations and function of science.

The proceedings were concluded by Prof. Ernest Barker, who in a charming discourse referred to many other points of Anglo-Czech cultural contact, and expounded the great debt which all Europe owes to Bohemia, Moravia and Slovakia. 